\title{
Hubungan Status Gizi dan Usia Menarche Dengan Dismenore Primer pada Remaja Putri
}

\author{
Suriani Beddu ${ }^{*}$, Sitti Mukarramah ${ }^{2}$, Viqy Lestahulu ${ }^{3}$ \\ 1,2,3 Poltekkes Kemenkes Makasar, Indonesia
}

Informasi Artikel:

Diterima: Mei, 2015

Disetujui: Oktober, 2015

${ }^{*}$ Korespondensi penulis. suriani_bd@gmail.com

\begin{abstract}
ABSTRAK
Dismenore primer merupakan permasalahan di bidang ginekologi yang banyak menyerang remaja putri. Dampak dari dismenore dapat mengganggu aktivitas remaja dan menyebabkan ketidakhadiran siswi di sekolah. Tujuan penelitian ini adalah untuk mengetahui hubungan status gizi dan usia menarche dengan dismenore primer pada remaja putri di SMA "N" Makassar. Penelitian ini dilaksanakan pada bulan Mei-Juni 2013. Penelitian ini adalah penelitian survei analitik dengan desain cross sectional. Jumlah populasi adalah 98 orang dan sampel yang diambil adalah 79 orang berdasarkan rumus Solvin dengan standar error 0,05 dengan tekhnik pemilihan sampel simple random sampling. Pengambilan data menggunakan lembar checklist yang berisi numeric rating scale dan pengukuran antropometri (tinggi badan dan berat badan). Analisis data yang digunakan adalah analisis univariat dan bivariat dengan menggunakan uji chi-square. Hasil analisis variabel status gizi dengan menggunakan uji statistik chi-square dengan pearson chi-square test menunjukkan nilai $p=0,008$, artinya terdapat hubungan yang bermakna antara status gizi dengan dismenore primer. Hasil uji statistik untuk variabel usia menarche menunjukkan $\mathrm{p}=0,006$ artinya terdapat hubungan yang bermakna antara usia menarche dengan dismenore primer.
\end{abstract}

Kata kunci:Dismenore, Gizi; Menarche

\begin{abstract}
Primary dysmenorrhea is a problem in the field of gynecology that affects many adolescent girls. The impact of adolescent dysmenorrhea can interfere with the activity and lead to students to abstain from schools. Abnormal nutritional status and age of menarche are a risk factor of rapid primary dysmenorrhea. This study aimed to determine the relationship of nutritional status and age at menarche to primary dysmenorrhea in high school girls in Makassar National High School from May to Juny 2013. The population was 98 students and the sample size was 79 people using Solvin formula with standard error of 0.05 with simple random sampling. This was an analytical survey with a cross sectional study design. Data collection used checklist sheet which contained numeric rating scale and anthropometric measurements (stature and weight). Analysis of the data used univariate and bivariate analysis with chi-square test. From the research, the nutritional status variables using chi-square test statistic with pearson chi-square revealed a p-value of 0.008, meaning that there was a significant relationship between nutritional status and primary dysmenorrhea. Statistical test results for the variable of age of menarche showed a p-value of 0.006, meaning that there was a significant relationship between age of menarche and primary dysmenorrhea.
\end{abstract}

Keyword: Dysmenorrhea, Nutrition, Menarche 


\section{PENDAHULUAN}

Dismenorea adalah nyeri yang dirasakan sewaktu haid dengan gejala yang kompleks berupa kram perut bagian bawah yang menjalar ke punggung atau kaki (Dorland, 2008). Dismenore merupakan permasalahan di bidang ginekologi yang banyak menyerang remaja putri. Dismenore yang sering terjadi adalah dismenore primer atau nyeri haid yang terjadi tanpa adanya kelainan pada alat reproduksi (Winkjosastro, 2008; Benson, dkk, 2009).

Prevalensi dismenore pada remaja putri di Indonesia dilaporkan sekitar 92\%. Insiden ini menurun seiring dengan bertambahnya usia dan meningkatnya kelahiran. Pada penelitian terdahulu yang dilakukan oleh Susanto, Nasruddin dan Abdullah (2013) di beberapa wilayah Kotamadya Makassar didapatkan, dari 997 remaja putri, 935 kasus $(93,8 \%)$ remaja diketahui menderita dismenore.

Salah satu permasalahan yang dapat menimbulkan dismenore primer adalah status gizi. Overweight merupakan faktor risiko dari dismenorea primer. Selain itu, overweight juga membawa peranan sebagai faktor risiko terjadinya dismenorea primer. Namun di sisi lain, seseorang dengan underweight ternyata juga dapat mengalami dismenorea primer. Berdasarkan data awal yang diperoleh dari informasi guru kelas, hampir separuh siswi sering mengeluh nyeri haid.

Untuk pertumbuhan yang normal, seorang remaja putri memerlukan kecukupan nutrisi, energi, protein, lemak, dan suplai semua nutrien yang menjadi basis pertumbuhan. Makanan yang bergizi tinggi dan berlemak tinggi yang berasal dari hewan menyebabkan pertumbuhan berat badan pada remaja putri, sehingga kadar estrogen meningkat. Kadar hormon yang meningkat ini nantinya akan mempengaruhi saat menarche dari seorang remaja putri. Usia menarche yang cepat adalah $<12$ tahun yang menjadi faktor risiko terjadinya dismenorea primer (Danielle, 2011).
Berdasarkan informasi bahwa banyak remaja yang mengalami dismenore primer, hal ini dikhawatirkan akan mengganggu aktifitas belajar mereka. Penelitian ini penting untuk dilakukan agar dapat mengetahui kejadian dismenore primer serta keterkaitannya atau hubungannya dengan status gizi dan usia menarche.

\section{BAHAN DAN METODE}

Jenis penelitian yang digunakan dalam penelitian ini adalah penelitian survei analitik dengan desain penelitian Cross Sectional. Survei Analitik adalah survei atau penelitian yang mencoba menggali bagaimana dan mengapa fenomena kesehatan itu terjadi. Kemudian, analisis dinamika korelasi antara fenomena atau antara faktor resiko dan faktor efek dilakukan.

Penelitian ini dilaksanakan di salah satu SMA di Makassar. Pengambilan data dilakukan pada bulan Mei - Juni 2013. Populasi dalam penelitian ini adalah semua siswi kelas X dan XI yang berjumlah 98 siswi. Sampel dalam penelitian ini adalah sebagian siswi kelas X dan X. Besar sampel dalam penelitian ini ditetapkan berdasarkan rumus Solvin. Kriteria inklusi pada penelitian ini adalah siswi yang bersedia menjadi subyek penelitian, siswa yang tidak memiliki kelainan ginekologi atau dismenore sekunder, dan siswi yang telah menarche.

Teknik pemilihan sampel penelitian ini adalah simple random sampling yang merupakan pengambilan sampel secara acak sederhana, yakni setiap anggota atau unit dari populasi mempunyai kesempatan yang sama untuk diseleksi sebagai sampel. Apabila besarnya sampel yang diinginkan itu berbeda-beda, maka besarnya kesempatan bagi setiap satuan elementer untuk terpilih pun berbedabeda pula. Tekhnik pengambilan sampel secara acak sederhana ini dibedakan menjadi dua cara, yaitu dengan mengundi anggota populasi (lottery technique) atau tekhnik undian, dan dengan menggunakan tabel bilangan atau angka acak (random number). Dalam penelitian ini, 
peneliti menggunakan lottery technique atau tekhnik undian.

Peneliti menggunakan instrumen penelitian melalui pengukuran IMT/U dengan menggunakan timbangan berat badan merek camry dan stature meter 2 meter yang sebelumnya telah diuji kebenarannya. Selain itu, peneliti juga menggunakan lembar checklist yang berisi Numeric Rating Scale (NRS) yang dibagikan kepada responden.

Analisis univariat dapat menggambarkan kriteria dari sampel yang diteliti, seperti keadaan status gizi, usia menarche, dan frekuensi yang mengalami dismenore primer. Analisis bivariat adalah tahapan untuk mengetahui apakah terdapat hubungan antara status gizi dan usia menarche terhadap dismenore primer dengan menggunakan Chi Square Test. Program analisis menggunakan perangkat lunak dengan tingkat kesalahan $\alpha=$ 0,05 . Penelitian ini senantiasa menjunjung tinggi kaidah-kaidah penelitian, yaitu informed Consent, anonimity, dan confidentiality.

\section{HASIL DAN PEMBAHASAN}

Hasil-hasil penelitian dapat dilihat pada tabel-tabel yang disajikan. Tabel 1 memperlihatkan hasil distribusi karakteristik responden berdasarkan usia.

Tabel 1

Distribusi Karakteristik Responden berdasarkan Usia

\begin{tabular}{rcc}
\hline Usia & Frekuensi & $\mathbf{( \% )}$ \\
\hline $15-16$ & 54 & 68,4 \\
$17-18$ & 25 & 31,6 \\
Jumlah & 79 & 100 \\
\hline
\end{tabular}

Sumber : Data Primer 2013

Berdasarkan pengelompokkan status gizi IMT/U menurut KEPMENKES No. 1995/ MENKES/ SK/ XII / 2010 didapatkan hasil yang dapat dilihat pada Tabel 2.
Tabel 2

Distribusi Status Gizi pada Remaja Putri

\begin{tabular}{ccc}
\hline Status Gizi & Frekuensi & $\mathbf{( \% )}$ \\
\hline Sangat Kurus & 0 & 0 \\
Kurus & 9 & 11,4 \\
Normal & 58 & 73,4 \\
Gemuk & 11 & 13,9 \\
Obesitas & 1 & 1,3 \\
\hline Jumlah & $\mathbf{7 9}$ & $\mathbf{1 0 0}$ \\
\hline
\end{tabular}

Sumber : Data Primer 2013

Sesuai dengan kriteria objektif yang telah ditetapkan, peneliti menggabungkan sangat kurus, kurus, gemuk dan obesitas menjadi kategori tidak normal, dikarenakan status gizi tersebut adalah faktor risiko terjadinya dismenore primer (Daftary dan Patky, 2008 ; Tangchai, Titapant, dan Boriboonhirunsarn, 2004). Penggabungan tersebut dapat dilihat pada Tabel 3.

Tabel 3

Distribusi Status Gizi pada Remaja Putri

\begin{tabular}{ccc}
\hline Status Gizi & Frekuensi & $\mathbf{( \% )}$ \\
\hline Normal & 58 & 73,4 \\
Tidak Normal & 21 & 26,6 \\
\hline Jumlah & $\mathbf{7 9}$ & $\mathbf{1 0 0}$ \\
\hline
\end{tabular}

Sumber : Data Primer 2013

Gambaran usia menarche pada remaja putri kelas X dan XI Tahun 2013 dapat dilihat pada Tabel 4.

Tabel 4

Distribusi Usia Menarche pada Remaja Putri

\begin{tabular}{ccc}
\hline $\begin{array}{c}\text { Usia } \\
\text { Menarche }\end{array}$ & Frekuensi & $\begin{array}{c}\text { Presentase } \\
(\%)\end{array}$ \\
\hline Cepat & 29 & 36,7 \\
Ideal & 50 & 63,3 \\
\hline Jumlah & $\mathbf{7 9}$ & $\mathbf{1 0 0}$ \\
\hline
\end{tabular}

Sumber : Data Primer 2013

Gambaran derajat nyeri dari dismenore primer didapatkan hasil yang dapat dilihat pada Tabel 5. 
Tabel 5

Distribusi Derajat Dismenore Primer pada Remaja Putri

\begin{tabular}{ccc}
\hline $\begin{array}{c}\text { Derajat } \\
\text { Dismenore } \\
\text { Primer }\end{array}$ & Frekuensi & $\begin{array}{c}\text { Presentase } \\
\mathbf{( \% )}\end{array}$ \\
\hline 0 & 26 & 32,9 \\
1 & 19 & 24,1 \\
2 & 23 & 29,1 \\
3 & 8 & 10,1 \\
4 & 3 & 3,8 \\
\hline Jumlah & 79 & 100 \\
\hline
\end{tabular}

Sumber : Data Primer 2013

Hasil penelitian yang menghubungkan status gizi dengan dismenore primer pada remaja putri di SMA Nasional Makassar yang diperoleh dapat dilihat pada Tabel 6 .

Tabel 6

Analisis Hubungan Status Gizi dengan Dismenore Primer pada Remaja Putri

\begin{tabular}{lcccc}
\hline \multicolumn{1}{c}{ Status } & \multicolumn{2}{c}{ Dismenorea } & Total & Nilai p \\
\cline { 2 - 3 } $\begin{array}{l}\text { Gizi } \\
\text { Normal }\end{array}$ & Ya & Tidak & & \\
Tidak & 24 & 58 & 0,008 \\
normal & 19 & 2 & 21 & \\
\hline Total & 53 & 26 & 79 & \\
\hline
\end{tabular}

Hasil penelitian yang menghubungkan usia menarche dengan dismenore primer pada remaja putri yang diperoleh dapat dilihat pada Tabel 7

Tabel 7

Hubungan Usia Menarche dengan Dismenore Primer.

\begin{tabular}{lllll}
\hline \multicolumn{1}{c}{ Usia } & \multicolumn{2}{c}{ Dismenorea } & Total & Nilai p \\
\cline { 2 - 3 } Menarche & Ya & Tidak & & \\
Ideal & 28 & 22 & 50 & \multirow{2}{*}{0,006} \\
Cepat & 25 & 4 & 29 & \\
\cline { 1 - 3 } Total & 53 & 26 & 79 & \\
\hline
\end{tabular}

Berdasarkan hasil pengolahan data pada Tabel 1 memperlihatkan adanya variasi pada usia responden yakni (15-18 tahun). Responden terbanyak adalah berada pada usia 15-16 tahun yaitu 54 orang $(68,4 \%)$, kemudian pada usia 17-18 tahun yaitu sebanyak 25 orang $(31,6 \%)$. Kelompok usia antara 15-18 tahun ini dapat dikatakan sebagai usia yang paling sering terjadi dismenore primer.

\section{a. Status Gizi}

Status gizi remaja ditentukan dari keadaan tubuh remaja yang dihitung berdasarkan IMT/U yang kategorinya (sangat kurus, kurus, normal, gemuk dan obesitas) berdasarkan KEPMENKES (2010) tentang Standar Antropometri Penilaian Status Gizi Anak dan Remaja. Menurut Jones (2008), status gizi merupakan keadaan kesehatan tubuh seseorang yang diakibatkan oleh konsumsi, penyerapan, dan penggunaan zat gizi makanan. Responden dengan status gizi tidak normal yang tidak mengalami dismenore primer adalah sebanyak 2 orang $(9,5 \%)$, dan yang mengalami dismenore primer adalah sebanyak 19 orang $(90,5 \%)$. Sementara itu, responden dengan status gizi normal yang mengalami dismenore adalah sebanyak 34 orang $(58,6 \%)$ dan yang tidak mengalami dismenore adalah sebanyak 24 orang $(41,4 \%)$.

Berdasarkan hasil analisis statistik yang menggunakan uji Chi Square Test dengan $\alpha=$ 0,05 pada Tabel 6 di atas diperoleh nilai $p=0,008$, yang artinya bahwa terdapat hubungan yang bermakna antara status gizi dengan dismenore primer. Hasil penelitian ini sesuai dengan teori yang mengatakan bahwa status gizi merupakan permasalahan yang dapat menimbulkan dismenore primer. Dalam buku Daftary dan Patky (2008), overweight/gemuk merupakan faktor risiko dari dismenorea primer. Selain itu, obese juga membawa peranan sebagai faktor risiko terjadinya dismenorea primer (Hamilton dan Morgan, 2009). Namun di sisi lain, seseorang dengan underweight/ kurus juga dapat mengalami dismenorea primer (Tangchai, Titapant, dan Boriboonhirunsarn, 2004).

Kelebihan berat badan dapat mengakibatkan dismenore primer karena di dalam tubuh orang yang mempunyai kelebihan berat badan terdapat jaringan lemak yang berlebihan yang dapat mengakibatkan hiperplasia pembuluh darah (terdesaknya pembuluh darah oleh jaringan lemak) pada organ reproduksi wanita sehingga darah yang 
seharusnya mengalir pada proses menstruasi terganggu dan timbul dismenore primer (Novia \& Puspitasari, 2008). Selain itu, Jeffcoate dalam Nataria (2011) mengatakan bahwa orang dengan Indeks Massa Tubuh yang lebih dari normal menunjukkan peningkatan kadar prostaglandin (PG) yang berlebih, sehingga memicu terjadinya spasme miometrium yang dipicu oleh zat dalam darah haid yang mirip lemak alamiah yang dapat ditemukan di dalam otot uterus.

Status gizi underweight dapat diakibatkan karena asupan makanan yang kurang. Status gizi merupakan bagian penting dari kesehatan seseorang. Gizi kurang selain akan mempengaruhi pertumbuhan dan fungsi organ tubuh juga akan menyebabkan terganggunya fungsi reproduksi. Hal ini berdampak pada gangguan haid termasuk dismenore, tetapi akan membaik bila asupan nutrisinya baik (Yustiana, 2011).

Hasil yang sama juga didapatkan dari penelitian terdahulu yang dilakukan oleh Susanto, Nasruddin, dan Abdullah (2008) yang menemukan adanya hubungan yang bermakna antara status gizi dengan dismenore primer.

\section{b. Usia Menarche}

Menurut Hinchliff dalam Proverawati dan Misaroh (2009), menarche adalah periode menstruasi yang pertama terjadi pada masa pubertas seorang wanita. Usia menarche yang ideal adalah 12 sampai dengan 14 tahun dan dikatakan menarche dini jika usia di bawah 12 tahun. Menurut Wiknjosastro (2008), perubahan-perubahan kadar hormon sepanjang siklus menstruasi disebabkan oleh mekanisme umpan balik antara hormon steroid dan hormon gonadotropin. Estrogen menyebabkan umpan balik negatif terhadap Follicle Stimulating Hormone (FSH) sedangkan terhadap Luteinizing Hormone (LH), estrogen menyebabkan umpan balik negatif jika kadarnya rendah dan umpan balik positif jika kadarnya tinggi.

Distribusi usia menarche pada remaja putri di SMA Nasional Makassar pada Tabel 4 menunjukkan bahwa, dari 79 responden, 29 orang (36,70\%) responden mengalami usia menarche cepat dan $50(63,29 \%)$ responden mengalami usia menarche ideal. Analisis hubungan usia menarche dengan dismenore primer pada Tabel 7 menunjukkan bahwa, dari 79 responden, responden dengan usia menarche cepat $(<12$ tahun) yang tidak mengalami dismenore primer adalah sebanyak 4 orang $(13,8 \%)$, dan yang mengalami dismenore adalah sebanyak 25 orang $(86,2 \%)$. Sementara itu, responden dengan usia menarche ideal (12-14 tahun) yang tidak mengalami dismenore primer adalah sebanyak 22 orang $(44,0 \%)$, dan yang mengalami dismenore adalah sebanyak 28 orang $(56,0 \%)$.

Berdasarkan hasil analisis statistik dengan menggunakan uji Chi Square Test dan $\alpha=0,05$ pada Tabel 7 diperoleh nilai $\mathrm{p}=0,006$, yang berarti bahwa terdapat hubungan yang bermakna antara usia menarche dengan dismenore primer. Hasil penelitian ini adalah sama dengan teori yang mengatakan bahwa usia menarche yang cepat menjadi faktor risiko terjadinya dismenorea primer (Danielle, 2011; Ningsih, 2010; Novia, 2008).

Kejadian dismenore primer sangat dipengaruhi oleh usia wanita. Rasa sakit yang dirasakan beberapa hari sebelum menstruasi dan saat menstruasi biasanya karena meningkatnya sekresi hormon prostaglandin. Semakin tua umur seseorang, semakin sering orang tersebut mengalami menstruasi dan semakin lebar leher rahim maka sekresi hormon prostaglandin akan semakin berkurang. Selain itu, dismenore primer nantinya akan hilang dengan makin menurunnya fungsi saraf rahim akibat penuaan (Novia 2008).

\section{KESIMPULAN}

Berdasarkan hasil penelitian tentang hubungan status gizi dan usia menarche dengan dismenore primer pada remaja putri di SMA Nasional Makassar tahun 2013, maka dapat disimpulkan sebagai berikut:

Terdapat hubungan yang bermakna antara status gizi dengan dismenore primer pada 
a. remaja putri di SMA "N" Makassar tahun 2013.

b. Terdapat hubungan yang bermakna antara usia menarche dengan dismenore primer pada remaja putri di SMA "N" Makassar tahun 2013.

\section{DAFTAR PUSTAKA}

Benson, dkk. 2009. Buku Saku Obstetri dan Ginekologi. Jakarta: EGC. 2009

Daftary dan Patky, 2009. Reproductive Endocrinology \& Infertility. New Delhi: BI Publications Pvt Ltd. 2009.

Danielle. 2011. Women's Health In General Practice. Australia: Churchill Livingstone.

Hamilton dan Morgan. 2009. Obstetri dan Ginekologi. Jakarta: EGC.

Dorland. 2002. Kamus Kedokteran Dorland. Jakarta: EGC.

Hamilton dan Morgan. Obstetri dan Ginekologi. Jakarta: EGC. 2009.

Jones. Dasar-dasar Obstetri \& Ginekologi. Jakarta: Hipokrates. 2001.

Keputusan Menteri Kesehatan Republik Indonesia Nomor 1995/MENKES/SK/XII/2010 tentang Standar Antoprometri Status Gizi Anak. Diambil dari http://gizi.depkes.go.id/wpcontent/uploads/2011/11/buku-skantropometri-2010.pdf diakses tanggal 01 Januari 2013

Nataria. 2011. Faktor-faktor yang Berhubungan Dengan Kejadian Dismenore Pada Mahasiswa Fakultas Kedokteran Universitas Pembangunan Nasional "Veteran" [skripsi]. Jakarta: Universitas Pembangunan Nasional "Veteran". 2011.

Ningsih., 2011 Efektifitas Paket Pereda Terhadap Intensitas Nyeri Pada Remaja Dengan Dismenore Di SMAN Kecematan Curup [tesis]. Jakarta: Universitas Indonesia.
Novia, Puspitasari. 2008. Faktor Risiko yang Mempengaruhi Kejadian Dismenore Primer.The Indonesian Journal of Public Health, Vol. 4, No. 2, 2008. pp.96-104.

Proverawati, Misaroh. 2009. Menarche. Yogyakarta: Medical Book.

Sarwono. 2010. Psikologi Remaja,Edisi Revisi. Jakarta: Raja Grafindo Persada. 2010.

Susanto, Nasrudindan Abdullah. 2013. Analisis Kasus Dismenore Primer Pada Remaja Putri di Kotamadya Makassar tahun 2008. Diambil dari http://med.unhas.ac.id/obgin. Diakses 01 Januari 2013.

Tangchai, Titapant, Boriboonhirunsarn. 2004. Dysmenorrhea In Thai Adolescent: Prevalence, Impact And Knowledge of Treatment. Journal of the Medical Association of Thailand, vol.87, nomer 3. pp.69-73.

Wiknjosastro.2008. Ilmu Kandungan. Jakarta: P.T. BinaPustaka Sarwono Prawirohardo.

Yustiana. 2011. Hubungan Status Gizi Dengan Keluhan Nyeri (Dismenore) Saat Menstruasi Pertama (Menarche) Pada Siswa SLTP Di Surakarta. Universitas Sebelas Maret: Artikel Digital Library. Diakses 01 Januari 2013 